\title{
Different serotypes of dengue virus (DENV) imported by Polish travellers from dengue endemic areas to Poland
}

\author{
Beata Biernat $^{1}$, Joanna Stańczak ${ }^{1}$, Beata Szostakowska ${ }^{1}$, Agnieszka Wroczyńska ${ }^{2}$, \\ Anna Kuna ${ }^{3}$, Wacław L. Nahorski ${ }^{2}$, Maria Racewicz ${ }^{1}$
}

\footnotetext{
${ }^{1}$ Department of Tropical Parasitology, Institute of Maritime and Tropical Medicine, Medical University of Gdansk, Poland ${ }^{2}$ Clinic of Tropical and Parasitic Diseases, Institute of Maritime and Tropical Medicine, Medical University of Gdansk, Poland ${ }^{3}$ University Centre for Maritime and Tropical Medicine, Gdynia, Poland
}

\begin{abstract}
Background: Dengue viruses are the most widespread arboviruses (transmitted mainly by Aedes aegypti and Ae. albopictus mosquitoes), which have shown an unexpected geographic expansion. There are four dengue virus serotypes: DENV-1, DENV-2, DENV-3, and DENV-4. Subsequent infections increase the risk of developing severe dengue fever.

Materials and methods: Samples from travellers returning from the endemic area of dengue fever were examined with the reverse transcription-polymerase chain reaction method. Primers amplified $743 \mathrm{bp}$ fragment of the NS5 and 3'UTR genomic region of mosquito-borne flaviviruses of JEV group were used. Results: The sequences from the 10 examined patients were compared to available DENV sequences in GenBank database and the basic local alignment search tool (BLAST) results confirmed that the infective virus was DENV-1 (6 patients), DENV-2 (2 patients) and DENV-3 (2 patients).

Conclusions: For the first time in Poland, dengue virus serotypes were determined in travellers returning from dengue-endemic areas.
\end{abstract}

(Int Marit Health 2015; 66, 2: 72-76)

Key words: dengue, DENV, dengue serotypes, travellers, Poland, reverse transcription-PCR

\section{INTRODUCTION}

Dengue fever is an acute infectious disease caused by DENV - a single stranded ribonucleic acid (RNA) virus of the family Flaviviridae, genus Flavivirus. Dengue virus (DENV) comprises of four genetically and antigenically distinct serotypes (DENV-1, DENV-2, DENV-3, and DENV-4) with numerous virus strains found worldwide [1].

The natural cycle of dengue involves human-mosquito-human transmission. Mosquitoes can also infect non-human primates in a sylvatic cycle [2], although symptoms typical for human infection are rarely seen in them [3]. Infection is transmitted by mosquitoes of the genus Aedes
(Stegomyia), mainly Ae. (S.) aegypti (L) [4], less frequently by the tiger mosquito Ae. (S.) albopticus (Skuse) [5] and other species of Aedes mosquitoes, e.g. the Polynesian tiger mosquito Ae. (S.) polynesiensis Marks. Vertical DENV transmission is possible (transovarial in mosquitoes) $[6,7]$ and with breast milk in humans [8]. Infection with any of these viruses can be asymptomatic, it may cause a self-limited febrile illness - dengue fever (DF), or it may result in a life-threatening syndrome called dengue haemorrhagic fever (DHF) or dengue shock syndrome (DSS) [9, 10]. Current criteria of the World Health Organisation (WHO) classify dengue according to its clinical severity: dengue without warning

Beata Biernat, PhD, Department of Tropical Parasitology, Institute of Maritime and Tropical Medicine, Medical University of Gdansk, ul. Powstania Styczniowego 9B,

81-519 Gdynia, Poland, e-mail: bebe@gumed.edu.pl 
signs, dengue with warning signs and severe dengue (dengue with severe plasma leakage, severe bleeding, or organ failure) [11]. Dengue is the most common mosquito-borne viral infection in the world, which is endemic in more than 100 countries in tropical and subtropical regions [12], many of which are popular tourist destination. After more than 6 decades autochthonous dengue cases have been reported in Europe again: in southern France $[13,14]$ and Croatia [15]. According to the WHO, global incidence of dengue has increased in recent decades and there are annually more than 50 million cases and 22,000 deaths [16, 17]. Actual numbers of both deaths and cases of disease due to dengue virus are certainly higher than those reported to the WHO [18]. Rapid dengue spread in the world may be associated with unplanned urbanisation, crowding, overpopulation, a weakened public-health infrastructure and international travel introducing new serotypes, genotypes and new strains to different parts of the world [19]. However, the factors influencing the increased frequency of dengue epidemics and severity are not fully understood [20].

Infection with one serotype of DENV can predispose for the development of severe dengue on reinfection with another serotype [21]. Dengue is rarely diagnosed in Poland; however, the number of Polish travellers to subtropics and tropics, including endemic regions where this illness occurs, increases every year [22].

In this study, we report some molecular data of DENV detected in blood and serum samples from Polish travellers returning from dengue endemic areas.

\section{MATERIALS AND METHODS}

A retrospective study was performed on serum and blood samples from patients from University Centre for Maritime and Tropical Medicine in Gdynia during the period 2007-2013. Routine laboratory diagnosis of dengue fever was performed at the Department of Tropical Parasitology, Institute of Maritime and Tropical Medicine, Medical University of Gdansk by detection of specific immunoglobulins using enzyme-linked immunosorbent assay Dengue IgM ELISA and Dengue IgG ELISA IBL (Hamburg, Germany). In both tests samples were considered positive if the absorbance value was higher than $10 \%$ over the cut-off, and negative if the absorbance was lower than $10 \%$ cut-off. Samples with an absorbance value of $10 \%$ above or below the cut-off were treated as equivocal.

Whenever possible, serum samples for molecular investigation were obtained from the earliest blood draw. Serum and blood samples ( $n=57$ ), for which IgM detection proved negative, borderline or positive, were qualified for molecular testing.

Viral RNA was extracted from blood and serum using a commercial Total RNA kit (A \& A Biotechnology, Gdynia,
Poland) according to the manufacturer's instruction and the obtained templates were kept frozen in $-80^{\circ} \mathrm{C}$ for further investigation. The primers specific for JEV group: forward WNV10090f 5'-GARTGGATGACVACRGAAGACATGCT-3' and reverse WNV10807r 5'-GGGGTCTCCTCTAACCTCTAGTCCTT-3', designed on the non-structural protein 5 (NS5) and 3'-untranslated region 3 (UTR3), respectively, were applied on the RNA extracts [23]. Reverse transcription-polymerase chain reaction (RT-PCR) was performed using QIAGEN OneStep RT-PCR Kit (Qiagen, Germany) as described previously [23]. PCRs were conducted in $20 \mu \mathrm{L}$ reaction mixture volume and under the conditions: $30 \mathrm{~min}$ at $50^{\circ} \mathrm{C}$ for reverse transcription, $95^{\circ} \mathrm{C}$ for initial denaturation followed by 40 cycles: $40 \mathrm{~s}$ at $94^{\circ} \mathrm{C}$ denaturation, $50 \mathrm{~s}$ at $57^{\circ} \mathrm{C}$ annealing, $1 \mathrm{~min}$ at $72^{\circ} \mathrm{C}$ extension and $7 \mathrm{~min}$ final extension at $72^{\circ} \mathrm{C}$ [24]. Positive (DENV-2 positive serum sample from previous investigation confirmed by sequencing) and negative (double distilled water - DDW instead of cDNA) controls were run with each RT-PCR reaction. All RT-PCR reactions were carried out in Mastercycler epgradient (Eppendorf) cycler. PCR products were analysed after electrophoresis in 1.5\% agarose gel stained with ethidium bromide. A $~ 700$ bp band was considered positive. Sequencing of PCR-positive products was carried out with $A B I$ Prism Big Dye Terminator v3.1 Cycle Sequencing Kit (Applied Biosystems), according to the manufacturer's instructions, and an ABI Prism 310 Genetic Analyser (Applied Biosystems, Foster City, CA, USA) automated sequencing system. Sequences were edited and compared with representative gene sequences deposited in GenBank database using NCBI BLAST software (http://www.ncbi.nlm.nih.gov/BLAST) (U.S. National Institute of Health, Bethesda, Maryland).

\section{RESULTS}

A retrospective study was performed on 57 blood and serum samples from 48 patients. Positive results were obtained from 10 (20.83\%) patients. The majority of them $(n=7)$ travelled to Southeast Asia (Thailand, Indonesia, Philippines and India), 2 to South America (Brazil) and 1 to Africa (Chad) (Table 1). Three dengue virus serotypes were identified: DENV-1, DENV-2 and DENV-3.

\section{DENGUE SEROTYPE 1}

DENV-1 was the most frequently detected serotype in our study. Altogether sequences of 6 isolates were identified: 3 from Southeast Asia (H26.PI; H27.PI, H58.PI), 2 from South America (H28.PI; H29.PI) and 1 from Africa (H40.PI) (Tables 1, 2).

The obtained sequence of isolate H26.PI from Indonesia showed $100 \%$ similarity with the deposited in GenBank sequence KC762653.1 from Indonesian patient (Table 2).

Of the 2 isolates from Thailand, sequence of $\mathrm{H} 27 . \mathrm{PI}$ was the most similar (99.4\%) to the 2 sequences KC762628 
Table 1. Dengue virus (DENV) serotypes imported to Gdynia, Poland in the years 2007-2013

\begin{tabular}{|c|c|c|c|c|}
\hline $\begin{array}{l}\text { DENV } \\
\text { serotype }\end{array}$ & $\begin{array}{l}\text { No. of } \\
\text { isola- } \\
\text { tes }\end{array}$ & $\begin{array}{l}\text { Country of origin/ } \\
\text { /No. of strains }\end{array}$ & & Isolate \\
\hline \multirow[t]{3}{*}{ DENV-1 } & 6 & South America 2 & $\begin{array}{l}\text { Brazil } \\
\text { Brazil }\end{array}$ & $\begin{array}{l}\text { H28.PI } \\
\text { H29.PI }\end{array}$ \\
\hline & & Africa 1 & Chad & H44.PI \\
\hline & & Asia 3 & $\begin{array}{l}\text { Indonesia } \\
\text { Thailand } \\
\text { Thailand }\end{array}$ & $\begin{array}{l}\text { H26.PI } \\
\text { H27.PI } \\
\text { H58.PI }\end{array}$ \\
\hline DENV-2 & 2 & Asia 2 & $\begin{array}{l}\text { Thailand } \\
\text { India }\end{array}$ & $\begin{array}{l}\text { H3.PI } \\
\text { H7.PI }\end{array}$ \\
\hline DENV-3 & 2 & Asia 2 & $\begin{array}{l}\text { Philippines } \\
\text { Thailand }\end{array}$ & $\begin{array}{l}\text { H17.PI } \\
\text { H44.PI }\end{array}$ \\
\hline
\end{tabular}

and KC762653 (human hosts) from Indonesia, while sequence of H58.PL to 2 sequences FJ196844 (cell culture) and FJ176779 (human host) from southern China (99\% homology) (Table 2).

Finally, the 2 sequences of isolates from South America, H28.PI and H29.PI, were identical to each other and differ by 1 nucleotide ( $99.8 \%$ level of the sequence similarity) from DENV-1 virus sequences from GenBank: KC629499; KC629505; KC629508; KC6294510 (C - T in position 10348), KC692501 (A - G in position 10264) (human hosts) from Argentina and EU482610 and FJ850102 ( $\mathrm{T}$ - C in position 10322) (human hosts) from Venezuela (Table 2).

The quality and length of the sequence from Chad $\mathrm{H} 40$. $\mathrm{PI}$ ) enabled dengue virus serotype 1 identification, however it was not possible to determine the highest identity level with any of homologous sequences deposited in the GenBank database.

\section{DENGUE SEROTYPE 2}

The partial sequence of DENV-2 obtained from patients who returned from Thailand (H3.PI) and India (H7.PI) showed 99.7\% homology to the sequence EU179858 from cosmopolitan Brunei DEN-2 virus genotype deposited in the GenBank database (Table 2).

\section{DENGUE SEROTYPE 3}

DENV-3 was identified in 2 patients who returned from Philippines (H17.PI) and Thailand (H44.PI). The sequence from Philippines showed $98.9 \%$ similarity to the deposited in GenBank sequence DQ675519 from a dengue fever patient from Taiwan (Tables 1, 2).

The quality of the sequence from Thailand enabled serotype 3 identification only, without further determination of homology with other sequences.

\section{DISCUSSION}

Until 2005, no epidemiological data and diagnostic tests were performed in Poland regarding dengue virus infection [22]. In the years 2006-2009, the serological tests performed in the University Centre for Maritime and Tropical Medicine demonstrated that 149 travellers (patients of the Clinic of Tropical and Parasitic Diseases of the Medical University of Gdansk and the Outpatient Clinic of Infectious, Tropical and Parasitic Diseases of the University Centre for Maritime and Tropical Medicine in Gdynia) who were subjected for routine examinations after the stay in the tropics might have been infected by DENV, 16 of the examined patients were diagnosed with dengue fever and 3 with dengue haemorrhagic fever [25]. In the same period, according to epidemiological reports by the National Institute of Hygiene and Chief Sanitary Inspectorate, 11 dengue cases were diagnosed in Poland [26-29]. In the years 2002-2011 in the Hospital Ward of Tropical Diseases and Zoonoses in Warsaw, 22 patients with the clinical course of the disease were hospitalised [30]. This data prove inadequate attention paid to this disease, despite the increase in recreational and occupational international travel, which include tropical and subtropical destinations. Autochthonous cases reported in southern Europe [13-15] show that this disease reemerged in Europe and the number of imported dengue cases in Poland may rise in the future. Dengue viraemia is short and is usually observed 2 to 3 days before the onset of fever, and lasts 4 to 5 days later [31], which explains why RNA was isolated only in 10 of 57 serum samples included into the study. Moreover, molecular studies are not routinely performed. Thus, blood samples are often taken in the disease phase in which serum antibody detection is probable, while at the same time viraemia is usually not seen.

Nucleic acid sequencing confirmed the homology of the three serotypes: DENV-1, DENV-2 and DENV-3. DENV-1 was the most frequently detected serotype within our study. This serotype was also seen most often in European travellers studied in the years 2002-2008 [20]. During the 70 years of studies on dengue serotypes spread and circulation, the majority of cases reported were caused by DENV-1 infection [32].

Dengue viruses can be isolated from the blood of patients during the early phase of acute dengue illness, when immunoglobulin $\mathrm{M}$ antibodies may not be detectable [1]. However, virus isolation requires the use of tissue culture assays, involving incubation periods of a week or longer. Molecular diagnostic systems using RT-PCR for detecting dengue viral RNA in human serum or plasma samples have been shown to be faster assays than cell culture and are highly effective for diagnosing dengue fever cases [33]. The mechanisms of dengue virus pathogenesis are little understood, however some studies showed that during 


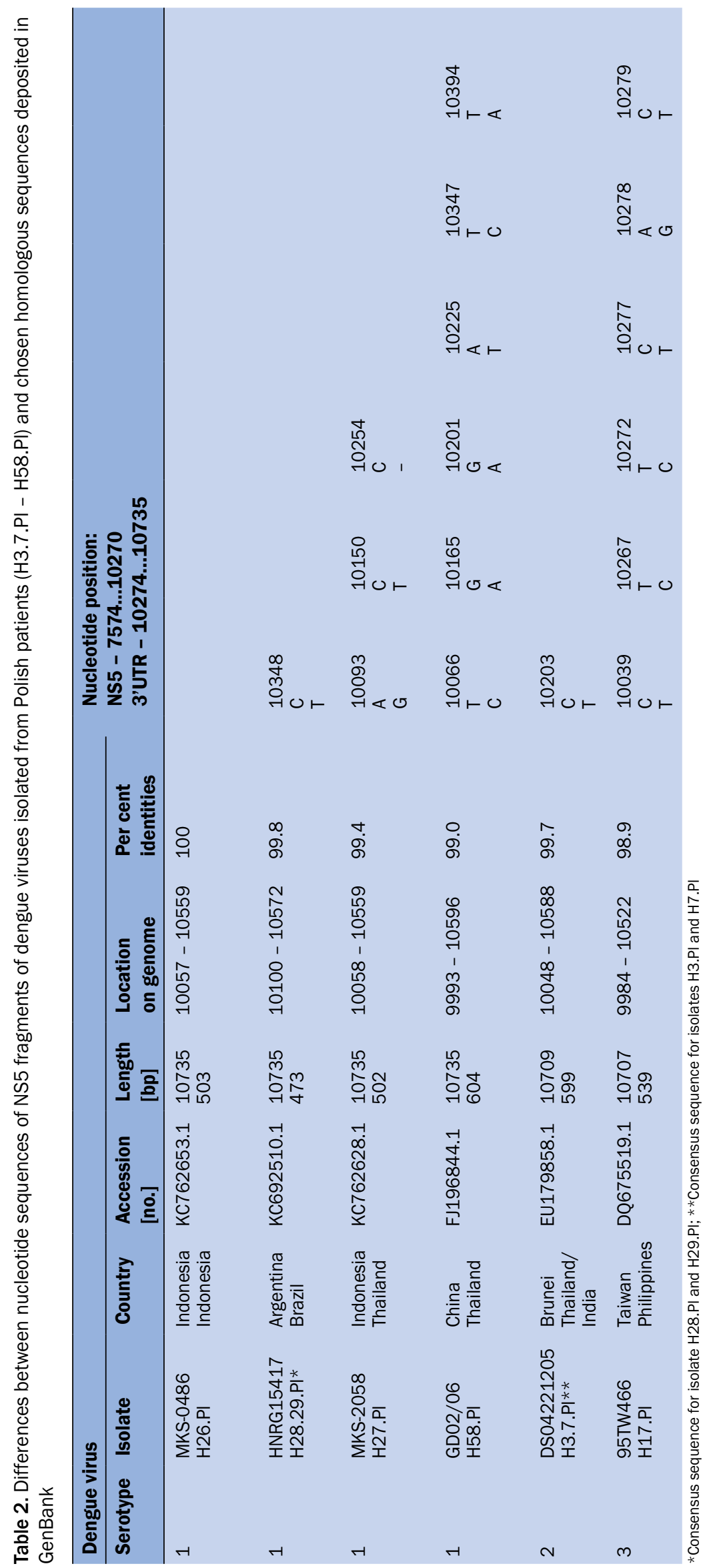


secondary dengue infections the pathophysiology of the disease changes significantly, particularly sequential infections in which infection with DENV-1 is followed by infection with DENV2 or DENV-3, or infection with DENV-3 is followed by infection with DENV-2 [34]. Secondary dengue infection is considered a risk factor for severe clinical course of the disease, which is explained by non-neutralising, cross-reacting antibodies from the first infection enhancing the infecting ability of the virus [35]. This phenomenon makes the information on DENV serotype responsible for the infection in the patient very important.

\section{CONCLUSIONS}

Along with the increase in numbers of travellers from Poland visiting dengue endemic areas, molecular methods of DENV detection should be introduced into the routine dengue diagnostics performed in this group of patients.

\section{ACKNOWLEDGEMENTS}

The study was funded by statutory activities 02-0024/07 in Medical University of Gdansk.

\section{REFERENCES}

1. Henchal EA, Putnak RJ. The Dengue Viruses. Clin Microbiol Rev 1990; 3: 376-396.

2. Fagbami AH, Monath TP, Fabiyi A. Dengue virus infections in Nigeria: a survey for antibodies in monkeys and humans. Trans R Soc Trop Med Hyg 1977; 71: 60-65.

3. Clark KB, Onlamoon N, Hsiao H-M, Guey C, Perng GC, Villinger F. Can non-human primates serve as models for investigating dengue disease pathogenesis? Front Microbiol 2013; 4: 305, doi:10.3389/fmicb.2013.00305.

4. Bancroft TL. On the aetiology of dengue fever. Aust Med Gaz 1906; 25: 17-18.

5. Simmons JS, St. John JH, Reynolds FHK. Experimental studies of dengue. Philipp J Sci 1931; 44: 1-247.

6. Khin MM, Than KA. Transovarial transmission of dengue virus by Aedes aegypti in nature. Am J Trop Med Hyg 1983; 32: 590-594.

7. Martins VE, Alencar $\mathrm{CH}$, Kamimura MT et al. Occurrence of natural vertical transmission of dengue- 2 and dengue-3 viruses in Aedes aegypti and Aedes albopictus in Fortaleza, Ceará, Brazil. PLoS ONE 2012; 7: e41386.

8. Barthel A, Gourinat A-C, Cazorla C, Joubert C, Dupont-Rouzeyrol M, Descloux E. Breast milk as a possible route of vertical transmission of dengue virus? Clin Infect Dis 2013; 57: 415-417.

9. Guzmán MG, Kourí G. Dengue: an update. Lancet Infect Dis 2002; 2: 33-42.

10. World Health Organization. Dengue and dengue hemorrhagic fever. Fact Sheet 2002; No. 117.

11. World Health Organization. Dengue: guidelines for diagnosis, treatment, prevention and control. Geneva, 2009.

12. Ratnam I, Leder K, Black J, Torresi J. Dengue fever and international travel. J Travel Med 2013; 20: 384-393.

13. La Ruche G, Souarès $Y$, Armengaud A et al. First two autochtonous dengue virus infections in metropolitan France, September 2010. Euro Surveill 2010; 15: 19676.

14. Marchand E, Prat C, Jeannin C et al. Autochthonous case of dengue in France, October 2013. Euro Surveill 2013; 18: 20661.
15. Gjenero-Margan I, Aleraj B, Krajcar D et al. Autochthonous dengue fever in Croatia, August-September 2010. Euro Surveill 2011; 16: 19805.

16. Kyle JL, Harris E. Global spread and persistence of dengue. Annu Rev Microbiol 2008; 62: 71-92.

17. World Health Organization. Dengue. Countries or areas at risk, 2011. Accessed: WHO, 2013; Available at: http://gamapserver.who.int/ mapLibrary/Files/Maps/Global_Dengue_Transmission.

18. Jelinek T, Mühlberger N, Harms G et al. Epidemiology and clinical features of imported dengue fever in Europe: sentinel surveillance data from TropNetEurop. Clin Infect Dis 2002; 35: 1047-1052.

19. Gubler DJ. The global emergence/resurgence of arboviral diseases as public health problems. Arch Med Res 2002; 33: 330-342.

20. Domingo C, Niedrig M, Gascón J et al. Molecular surveillance of circulating dengue genotypes through European travelers. J Travel Med 2011; 18: 183-190.

21. Halstead S. Pathogenesis of dengue: challenges to molecular biology. Science 1988; 239: 476-481.

22. Nahorski WL, Chomicz L, Biernat B, Szostakowska B, Wroczyński P. $A$ vector control as intervention tool in arthropods-born dengue virus (DENV) infection in humans. In: Buczek A, Błaszak C eds. Arthropods. Threat to human and animal health. Koliber, Lublin 2014, pp. 85-92.

23. Weissenbock H, Kolodziejek J, Url A, Lussy H, Rebel-Bauder B, Nowotny N. Emergence of Usutu virus, an African Mosquito-Borne Flavivirus of the Japanese Encephalitis Virus Group, Central Europe. Emerg Infect Dis 2002; 8: 652-656.

24. Bakonyi T, Ivanics E, Erdelui K, Ursu K, Ferenczi E, Weissenbock H, Nowotny N. Lineage 1 and 2 Strains of Encephalitic West Nile Virus, Central Europe. Emerg Infect Dis 2006; 12: 618-623.

25. Goljan J, Myjak P, Nahorski W et al. Dengue antibodies in Polish travellers returning from the tropics. Evaluation of serological tests. Int Marit Health 2010; 61: 36-40.

26. Czarkowski MP, Cielebąk E, Dacka P, Kondej B. Infectious diseases and poisonings in Poland in 2006. National Institute of HygieneNational Research Center of Public Health, Chief Sanitary Inspectorate, Warszawa 2007.

27. Czarkowski MP, Cielebąk E, Dacka P, Kondej B. Infectious diseases and poisonings in Poland in 2007. National Institute of Hygiene National Research Center of Public Health, Chief Sanitary Inspectorate, Warszawa 2008.

28. Czarkowski MP, Cielebąk E, Kondej B, Staszewska E. Infectious diseases and poisonings in Poland in 2008. National Institute of Hygiene - National Research Center of Public Health, Chief Sanitary Inspectorate, Warszawa 2009.

29. Czarkowski MP, Cielebąk E, Kondej B, Staszewska E. Infectious diseases and poisonings in Poland in 2009. National Institute of Hygiene - National Research Center of Public Health, Chief Sanitary Inspectorate, Warszawa 2010.

30. Olszyńska-Krowicka M, Świtaj K. Denga u pacjentów hospitalizowanych w Klinice Chorób Odzwierzęcych i Tropikalnych w Warszawie w ostatnim dziesięcioleciu (2002-2011). Przeg| Epidemiol 2011; 65: 571-575.

31. Guzmán MG, Kourí G. Dengue diagnosis, advances and challenges. Int J Infect Dis 2004; 8: 69-80.

32. Messina JP, Brady OJ, Scott TW et al. Global spread of dengue virus types: mapping the 70year history. Trends Microbiol March 2014; 22: 138-145.

33. Wu S-JL, Lee EM, Putvatana R et al. Detection of dengue virus RNA using a nucleic acid sequence-based amplification assay. J Clin Mirobiol 2001; 39: 2794-2798.

34. Guzmán MG, Halstead SB, Artsob H et al. Dengue: a continuing global threat. Nat Rev Microbiol 2010; 8 (12 Suppl.): 7-16.

35. Wilder-Smith A. Dengue infections in travellers. Paediatr Int Child Health 2012; 32 (Suppl. 1): 28-32. 